\title{
Maternity, science and pandemic: an urgent call for action!
}

\author{
Maria Beatriz Rossi Caruzo ${ }^{1,4}$, (1) Manuela de Oliveira Ramalho ${ }^{2}$, (D) Juliana Philipp ${ }^{3}$ and (i) Cibele Bragagnolo
}

Received: 29.06.2020; accepted: 21.07.2020

How to cite: Caruzo, M.B.R., Ramalho, M.O., Philipp, J. \& Bragagnolo, C. 2020. Maternity, science and pandemic: an urgent call for action! Hoehnea 47: e812020. http://dx.doi.org/10.1590/2236-8906-81/2020

\begin{abstract}
Maternity, science and pandemic: an urgent call for action!). Historically, women have been subjected to the rules of patriarchal society and the unfair assignments of a sexual division of labor. A female transition from the household to join the workforce did not come with equal division of labor at home, which has been occurring recently on a small scale. In the field of Science, women have always had to face the prejudices and the misogyny of this patriarchal society. Therefore, female academic success is disproportionate to their male counterparts. Having children also plays a significant role in the declining numbers of women in advanced scientific careers and it is clear that the inequalities in the conditions of broad development of the academic career result in an overlap of weaknesses imposed specially on the career of the mother-scientists. Many scientists have had to change their routine and working relationships in response to the COVID-19 pandemic and are adapting to this new reality of remote work. Meanwhile, mother-scientists, especially with young children, are facing challenging situations. In recent years, women have been reaching collective actions to address and resolve injustices in the field of science and we cannot allow this pandemic to pull us into irreparable setbacks. Here we bring to light problems that mother-scientists are facing during the COVID-19 pandemic and call attention to the losses that will occur if we do not take an urgent action. Keywords: academic mothers, coronavirus, gender inequality
\end{abstract}

RESUMO - (Maternidade, ciência e pandemia: um apelo urgente à ação!). Historicamente, as mulheres foram submetidas às regras da sociedade patriarcal e às atribuições injustas de uma divisão sexual do trabalho. A transição feminina da esfera doméstica para ingressar na força de trabalho não ocorreu com igual divisão do trabalho em casa, o que vem ocorrendo recentemente em pequena escala. No campo da ciência, as mulheres sempre tiveram que enfrentar os preconceitos e a misoginia desta sociedade patriarcal. Portanto, o sucesso acadêmico feminino é desproporcional ao dos homens. Ter filhos também tem um papel significativo no número decrescente de mulheres em carreiras científicas avançadas e, assim, fica claro que as desigualdades nas condições de um amplo desenvolvimento da carreira acadêmica resultam em uma sobreposição de fragilidades impostas especialmente à carreira das mães-cientistas. Muitos cientistas tiveram que mudar suas rotinas e relações de trabalho em resposta à pandemia do COVID-19 e estão se adaptando a essa nova realidade de trabalho remoto. Enquanto isso, mães-cientistas, especialmente com crianças pequenas, estão enfrentando situações desafiadoras. Nos últimos anos, as mulheres vêm alcançando ações coletivas para tratar e resolver injustiças no campo da ciência e não podemos permitir que essa pandemia nos instale retrocessos irreparáveis. Aqui, trazemos à luz os problemas que as mães-cientistas estão enfrentando durante a pandemia de COVID-19 e chamamos a atenção para as perdas que ocorrerão se não tomarmos uma ação urgente. Palavras-chave: coronavírus, desigualdade de gênero, mães acadêmicas

Historically, women have been subjected to the rules of patriarchal society and the unfair assignments of a sexual division of labor. Many women were confined to domestic work, deprived of professional training and competitive insertion in the male-dominated labor market. With the contemporary feminist movement that started in the United States of America in the second half of the 1960s and expanded to the vast majority of industrialized countries in

1. Universidade Federal de São Paulo, Departamento de Ecologia e Biologia Evolutiva, Campus Diadema, Rua Prof. Artur Riedel, 275, Jd. Eldorado, CEP 09972-270, Diadema, SP, Brasil

2. Cornell University, College of Agriculture and Life Sciences, Entomology Department, 129, Garden Ave., Ithaca, NY, 14853, USA

3. Field Museum, Keller Science Action Center, 1400 Lake Shore Drive, Chicago, IL, 60605, USA

4. Corresponding author: mbrcaruzo@unifesp.br 
the late 1970s, women entered in great numbers into the labor market, including the Science field. However, this movement did not lead to substantial changes in society, which remains patriarchal to this day. In Brazil, for instance, women began to fulfill professional functions but were always pressured, criticized, and discriminated against for not fulfilling their stereotyped role as women defined by a male oriented society. Female transition from the household to join the workforce did not come with equal division of labor at home, which has been occurring recently on a small scale. Consequently, women were subjected to a double workday.

In the field of Science, women have always had to face the prejudices and the misogyny of a patriarchal society. According to the study "Deciphering the code: education of girls and women in science, technology, engineering and mathematics (STEM)", published by the United Nations Educational, Scientific and Cultural Organization (UNESCO), only $35 \%$ of the world's students in STEM Programs (Science, Technology, Engineering, and Mathematics) are women. While women receive the majority of STEM scholarships for undergraduate internships (55\%), master's degrees $(52 \%)$, doctorate degrees $(50 \%)$, and postdoctoral positions (53\%), according to data from Conselho Nacional de Desenvolvimento Científico e Tecnológico (CNPq), Instituto Nacional de Estudos e Pesquisas Educacionais Anísio Teixeira (INEP) and Parent in Science group (https://www.parentinscience.com), they only receive 23\% of grants from the highest levels of research productivity (CNPq - A1). In other words, female academic success is disproportionate to their male counterparts. This situation results from several factors, such as impostor syndrome, maternity leave, discrimination and sexual harassment. These and other factors often influence a woman's decision to interrupt or abandon her academic career.

Having children also plays a significant role in the declining numbers of women in advanced scientific careers. During undergraduate and graduate studies, women are frequently childless and are able to be fully dedicated to their academic life, and this is reflected in the greater number of scholarships for women. However, as women advance to higher academic levels, they are also more likely to have children, which often restricts the amount of time they can dedicate to scientific work. Most men, on the other hand, maintain full time employment and dedication to conduct their research. According to a survey led by the Parent in Science group, childless scientists have an upward curve in their scientific production, while mother scientists have a drastic drop in publications until the fourth year after the birth of their first child. However, this rise after the fourth year is compromised by the difficulty in keeping up with new scientific advances in the field, obtaining assistance from funding agencies and remaining in graduate programs.

In a recently published study on the impacts of parenting on the life of a myrmecologist (those who study ants), it was revealed that even after the child's fifth years parents still suffer an impact regarding work activities that escape the daily routine such as field trips and participation in meetings. Field trips, participation in conferences, and interaction with students and other researchers are part of the scientific career. Therefore, institutional actions are necessary to guarantee the participation of scientists parents in events that can be critical to the success of their career. These, and other challenges faced by scientific parents, especially mothers, will impact in the rest of their careers, with discrepancies in the distribution of productivity grants, just one of the metrics indicatives of these differences.

Thus, it is clear that the inequalities in the conditions of broad development of the academic career result in an overlap of weaknesses imposed specially on the career of the mother-scientists. According to data from the Instituto Brasileiro de Geografia e Estatística (IBGE), women spend almost twice as much time on housework and childcare as men. In the case of mother scientists, gender asymmetries tend to increase in this pandemic period, given that academic work requires a lot of focus and time to concentrate. These characteristics confront the urgent demands of young children, making the reconciliation of the two tasks incompatible. Editors of several scientific journals have observed a decline in the number of papers submitted by women during this pandemic period, whereas there was a $50 \%$ increase in submissions of scientific papers by men. The submission of women's papers as the first author, which averaged $37 \%$ between 2016 and 2020, dropped to $13 \%$ in the second quarter of 2020. It is inevitable to imagine that in one or two years the curricula will reflect this sharp imbalance, further exacerbating gender differences that are already prevalent across academia.

Many scientists have had to change their routine and working relationships in response to the pandemic and are adapting to this new reality of remote work. Some scientists are taking advantage of the release of faceto-face, administrative and teaching activities to devote themselves more to scientific research and the publication of papers. What was previously done with much more time and scientific rigor, is now published in a few days, in the race for understanding about the disease and in the search for new drugs and a vaccine. But this change is not limited only to research related to SARS-CoV-2, the scientific community as a whole has been faced with a new reality. Meanwhile parents, especially with young children, are facing challenging situations. What we are facing with COVID-19 disease is unprecedented in the history of modern society and we must rely on expert data to rebuild a more just and inclusive society for all. Science helps to understand the world around us and improve the quality of life for humanity. With all this potential, science should be equally accessible and inclusive to everyone. Rethinking our society, deadlines, models and expectations is urgent and extremely necessary to try to compensate for the injustices that this pandemic is making us face. 
In recent years, women have been reaching collective actions to address and resolve injustices in the field of science and we cannot allow this pandemic to pull us into irreparable setbacks. We need to continue to encourage female presence in the academic environment at all levels, pointing out gender discrepancies and injustices, building and supporting each other in building action proposals that lead to significant changes in the current system.

One overarching causes is that the majority of the positions of directors and scientific advisers are mainly occupied by men, who have the power to grant scholarships in financial agencies and research institutions, and several studies have already shown that there is the tendency for same sex gender bias. In this way, women in science will hardly be able to reverse these gender asymmetries. Therefore, we urgently need affirmative actions and policies to mitigate these injustices. Gender asymmetries must be taken into account by institutions when deciding on the distribution of funding, career advancement or assignment of leadership positions. Graduate scholarships need to be expanded during the pandemic period so that motherscientists are not left destitute at this time. Without the implementation of these remedial measures, in some years the discrepancies in the curricula will reflect the sum of inequalities imposed by gender and maternity, aggravated by the COVID-19 pandemic.

\section{Recommended literature}

Boueri, A.G. \& de Assis, C. 2018. Sem considerar maternidade, ciência brasileira ainda penaliza mulheres. Gênero e Número. Disponível em http://www. generonumero.media/sem-considerar-maternidadeciencia-brasileira-ainda-penaliza-mulheres/ (access in 15-VI-2020).

Candido, M. R. \& Campos, L.A. 2020. Pandemia reduz submissões de artigos acadêmicos assinados por mulheres, Blog DADOS. Available at http://dados. iesp.uerj.br/pandemia-reduz-submissoes-de-mulheres/ (access in 15-VI-2020).

De Pierro, B. 2020. Mães na quarentena: Isolamento social lança luz sobre desigualdade de gênero na ciência. Revista FAPESP. Available at https://revistapesquisa. fapesp.br/maes-na-quarentena/ (access in 10-VI-2020).
Elsevier. 2017. Gender in the global research landscape. Amsterdam: Elsevier. Available at https://www.elsevier. com/research-intelligence/resource-library/ty/gender-inthe-global-research-landscape (access in 15-VI-2020).

Kitchener, C. 2020. Women academics seem to be submitting fewer papers during coronavirus. 'Never seen anything like it,' says one editor. The Lily. Available at https://www.thelily.com/women-academics-seemto-be-submitting-fewer-papers-during-coronavirusnever-seen-anything-like-it-says-one-editor/ (access in 10-VI-2020).

Minello, A. 2020. The pandemic and the female academic. Nature. Available at https://www.nature.com/articles/ d41586-020-01135-9 (access in 10-VI-2020).

Myers, K.R., Tham, W.Y., Yin, Y., Cohodes, N., Thursby, J.G., Thursby, M.C., Shiffer, P., Walsh, J.T., Lakhani, K.R. \& Wang, D. 2020. Unequal effects of the COVID-19 pandemic on scientists. Nature Human Behaviour. Available at https://www.nature.com/articles/ s41562-020-0921-y (access in 19-VII-2020).

Quaglio, F., Cardoso, P.F.G. \& Bertoncini, C.R.A. 2020. Maternidade e Ciência em Tempos de Pandemia: Casa, Comida e Artigo Publicado. Adunifesp, Associação dos Funcionários da UNIFESP. Available at https:// adunifesp.org.br/maternidade-e-ciencia-em-temposde-pandemia-casa-comida-e-artigo-publicado/ (access in 12-VI-2020).

Ramalho, M.O., Decio, P., de Albuquerque, E. Z. \& Esteves, F. 2020. Parenting in the field of myrmecology: career challenges in the 21st century. Boletim do Museu Paraense Emílio Goeldi-Ciências Naturais 15: 27-37. https://doi.org/10.46357/bcnaturais.v15i1.255

Staniscuaski, F., Reichert, F., Werneck, F.P., Oliveira, L., Mello-Carpes, P.B., Soletti, R.C., Almeida, C.I., Zandona, E., Ricachenevsky, F.K., Neumann, A., Schwartz, I.V.D., Tamajusuku, A.S.K., Sixas, A., Kmetzsch, L. \& Parent in Science Movement. 2020. Impact of COVID-19 on academic mothers. Science 368: 6492. https://doi.org/10.1126/science.abc2740

UNESCO BRASIL. 2018. Decifrar o código: das meninas e mulheres em ciências, tecnologia, engenharia e matemática (STEM). Brasília. https://unesdoc.unesco. org/ark:/48223/pf0000264691 